\title{
Integration of Groundwater Modelling with Mine Planning to Optimise Mine Closure Plans - The Marillana Creek (Yandi) Mine Story
}

\author{
J.W. Hall Aquaterra, Australia \\ H. Middlemis Aquaterra, Australia \\ P.J. Waters BHP Billiton Iron Ore, Australia \\ K.L. Rozlapa Aquaterra, Australia
}

\section{$1 \quad$ INTRODUCTION}

A major challenge for closure planning at mining operations below water table is evaporation from final void pit lakes, which can impact on downstream groundwater (and surface water) flows and quality. A closure approach that is increasingly being adopted is to infill the final voids with waste rock to above the premining water table to prevent the development of a pit lake and subsequent evaporative losses. At BHP Billiton Iron Ore's Marillana Creek (Yandi) mine, where the orebody is a channel iron deposit that forms the major aquifer in the region, this approach is not practical. With a stripping ratio of less than one, there is insufficient waste rock to infill all mine areas to the pre-mining water table. Through the integration of hydrogeological modelling with mine planning, a cost effective solution was developed, which involved selective infilling of all pits, largely using run-of-mine waste dumping, and some diversion of surface water flows. This solution will result in maintenance of adequate groundwater and surface water flows to support downstream water dependent ecosystems and maintain beneficial use.

\section{BACKGROUND}

The orebody at BHP Billiton Iron Ore's (BHPBIO's) Marillana Creek (Yandi) mining operation is a Channel Iron Deposit (CID) that also forms the major aquifer in this part of the Pilbara region of Western Australia. The Marillana CID aquifer, a confined to semi confined aquifer which occupies a palaeochannel of Marillana Creek, extends some $20 \mathrm{~km}$ downstream of BHPBIO leases (through Rio Tinto - Pilbara Iron leases) to a confluence with the Weeli Wolli Creek CID, which eventually discharges into mixed alluvium within the Fortescue Marsh valley system. The Fortescue Marsh is a terminal wetland and underlying saline aquifer system within the Fortescue River valley.

Marillana Creek itself is an ephemeral surface water flow system, with an associated shallow $(<5 \mathrm{~m}$ thick) alluvial aquifer that supports a range of groundwater-dependent vegetation and related ecosystems. The present course of Marillana Creek crosses over the CID aquifer at several locations. Recharge to the CID aquifer occurs at these locations and where the creek flows adjacent to the CID, but only during those few weeks of the year when Marillana Creek flows (sporadic times following major rainfall events during the 3-4 month wet season). The CID aquifer itself is not thought to directly support the alluvium or the phreatophytic vegetation.

There is little development pressure for the current or future consumptive use of the groundwater resource, other than for mining and cattle operations (potable to stock quality beneficial use status). The total annual volumes of both groundwater flow within the CID (and alluvial) aquifers and surface water flows in Marillana Creek form only a small $(<10 \%)$ contribution to the water balance of the Fortescue Marsh (Aquaterra, 2000).

The narrow ( $<800 \mathrm{~m}$ ) Marillana Creek orebody will be completely mined over the next 30 years as a series of open pits up to $90 \mathrm{~m}$ deep, extending over more than $20 \mathrm{~km}$ in length on the BHPBIO lease (Figure 1). Around half the resource lies below the water table, but with an overburden stripping ratio of $0.35: 1$, there is 
insufficient waste material to backfill the final open cut voids to above the water table. Therefore, the Yandi closure plan needs to address the issue of the development of final void pit lakes, with subsequent evaporation and concentration of salts, which can impact on downstream groundwater (and surface water) flows and quality.

Hydrogeological investigations and initial groundwater modelling indicated that standard mine closure approaches (e.g. no infill, or direct in-fill only to the closest mine void, no double-handling of waste etc) would result in the development of large pit void lakes which would become saline sinks. The investigations indicated that the residual mine void geometry needed to be optimised to minimise evaporation and maximise throughflow. This paper describes the outcomes from a program of detailed investigations and modelling by Aquaterra, in close consultation with BHPB Iron Ore mine planning and environmental staff, to develop practical and cost effective life of mine mining and waste handling schedules to achieve a sustainable closure plan. This paper does not deal in detail with the stream diversion issues.

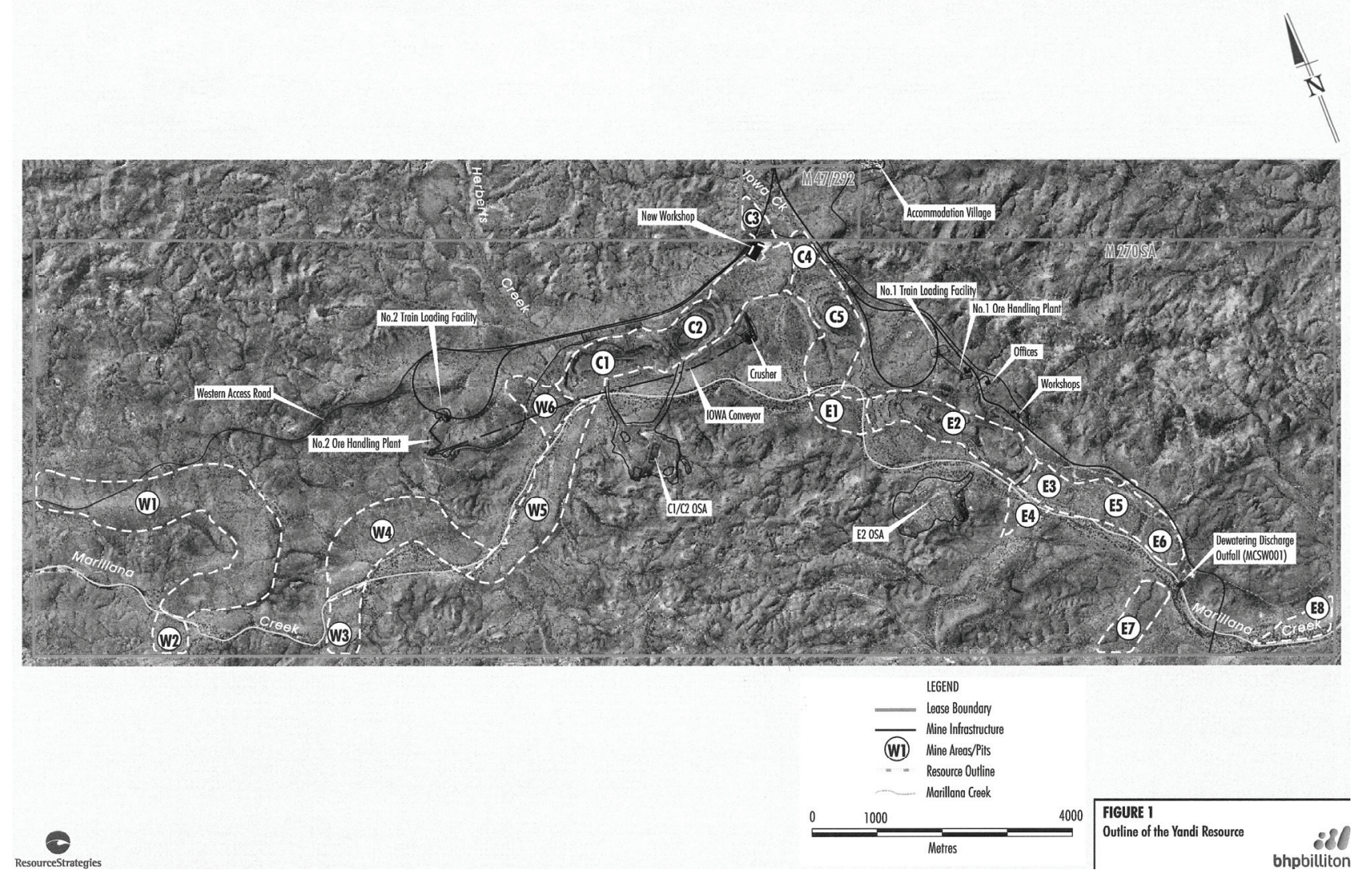

Figure 1 Outline of the Yandi resource

\section{GUIDING PRINCIPLES FOR MINING AND MINE CLOSURE}

On consideration of the implications of the initial hydrogeological investigations, BHPBIO established a set of "guiding closure principles" for surface water and groundwater resources, landforms and vegetation, which were used to guide development of a Decommissioning and Final Rehabilitation Plan (BHPBIO, 2004).

The Decommissioning Plan was prepared using the results from an iterative work program of groundwater modelling of different waste rock infill distributions. In this way, waste rock infilling of mine voids was optimised to meet the overall economic mine plan, within the constraints of the guiding principles for mine closure.

Following submission of the Decommissioning Plan to government, the guiding principles were also adopted, with some refinements, in the Ministerial conditions applying to the Life of Mine Plan (Bulletin 
1166 at www.EPA.wa.gov.au). The conditions required BHPBIO to prepare a 'walk away solution for the decommissioned mine site', consistent with commitments by BHPBIO to ensure that rehabilitation achieves a stable and functioning landform that does not require ongoing intervention or management.

The guiding principles for mine closure required the application of best practice approaches to maintain the multiple values of the Marillana Creek hydrological systems in space and time. That is, the existing surface water and groundwater resource functions should be retained during the life of mine operations and also post-mining. More than 10 years of mining operations have shown that the existing values have indeed been retained during mining. The focus of this paper is on the post-closure measures that have been developed.

The following points summarise the adopted guiding principles for mine closure planning:

- Use at least $90 \%$ of the overburden/waste material to partially infill mine voids, with a distribution designed to maintain groundwater throughflow along the mine path (through areas of overburden infill and residual pit lakes) and at the downstream end of the lease, and to minimise salinity build-up.

- Maintain the suitability of the groundwater quality along the mine path and in the pit lakes for the determined beneficial use status (sub-potable to stock water quality) and ecosystem function.

- Retain some groundwater recharge interaction processes between Marillana Creek and the palaeochannel at cross-over points.

- Divert Marillana Creek away from mining areas, but maintain the integrity of the Creek surface water system upstream and downstream of the diversions, and design the diversion to mimic the existing fluvial system.

- Allow diversion of some (northern) tributaries into the mine path to enhance groundwater system attributes, but discharge the southern tributaries into the original or the diverted channel, with allowance for diversions of creek flows in excess of 1:100 year events at the upstream end of the mine path.

The Marillana Creek groundwater model was used to evaluate options for waste rock infill distribution that would meet the above guiding principles.

\section{$4 \quad$ MARILLANA CREEK GROUNDWATER MODEL}

The Marillana Creek regional groundwater flow model was originally developed in 1995 for the main purpose of evaluating options for mine closure at (then) BHP Iron Ore's Yandi mines. In summary, the Marillana Creek groundwater model was developed using the industry-standard Modflow code, and it has the following features:

- Four layers to represent the major aquifer units, and provide the capability to represent surfacegroundwater interaction between residual aquifers and pit lakes.

- Broad scale seasonal rainfall recharge.

- Measured sporadic stream flow at the upstream end of the Marillana Creek feature in the model, plus estimated (ungauged) tributary inflows, and subsequent model calculation of leakage to aquifers (Modflow streamflow-routing package).

- Depth-dependent and spatially-variable evapotranspiration from phreatophytes along Marillana Creek.

- Time series of mine dewatering and subsequent discharge to the creek at multiple locations.

The Marillana Creek groundwater model was originally calibrated using 5 years of monitoring data on groundwater levels and 3 years of dewatering abstractions and discharge for the first active pit (E2) at that time (Middlemis and Rozlapa, 1998). The rainfall and stream flow data used for model calibration included the extended dry periods of 1992 to 1994 and the major flood event of Cyclone Bobby in January 1995. Since 1995, the model calibration (history match) has been tested several times against new climatic and dewatering data, with very few and very minor parameter adjustments needed to validate its predictive capacity. The new data also included monitoring associated with major dewatering operations at multiple 
new BHPBIO pits. In 2000, Hamersley Iron (now Pilbara Iron) also provided data on their Yandicoogina dewatering operation that were not available during model development, and this was used in a successful blind validation run (Aquaterra, 2000). The model validation has also been confirmed against data on the substantial variability of hydrological cycles over almost 13 years to early 2003, and the record wet seasons in 1999, 2000, and early 2003. The model has been reviewed by government agencies, and has also been independently reviewed (Kalf and Associates, 2000).

The Marillana Creek groundwater model has been proven to be a robust predictive tool. There are very few models that have successfully been through such a rigorous program of calibration, validation, independent review and post-audit, notwithstanding that few refinements were needed to maintain model performance.

The Marillana Creek groundwater model has since been successfully used for the following multiple purposes:

- Evaluating mine closure options involving selective waste rock infill to maintain groundwater throughflows and water quality, to support the closure planning process.

- Developing optimum dewatering strategies and outlining schedules for life of mine dewatering programs, to support mine planning and expansion approvals.

- Evaluating catchment water balances and dewatering/discharge impacts on groundwater dependent ecosystems due to BHPBIO's Yandi and Pilbara Iron's Yandicoogina mining operations, to support resource assessment programs for the Water and Rivers Commission (now Department of Water).

For use in the mine closure planning, a long term (1000 year) stream flow data set was derived (Gilbert and Associates, 2003), for input to the groundwater model for the main creek and tributaries. The median (P50) stream flow data set was applied to the groundwater model for the post-mining simulations of 50 years under the various waste infill configurations, with the additional diversion into selected upstream pit lakes of a portion of flows in excess of 1:100 year events. It was found that the groundwater and pit lake levels recovered to an equilibrium level within about 10 years for all cases. Sensitivity runs were also undertaken on the finally adopted waste infill configuration, to consider the 50 year data sets of stream flows for the wettest (P10) and driest (P90) conditions. The stream feature in the model was also adjusted to represent the diverted stream alignment and character.

In addition to representing the geometry of the waste rock infill configuration, aquifer parameter values were adjusted in the model to represent the void with a very high permeability and $100 \%$ porosity. Evaporation on the void areas was specified at a maximum of $50 \%$ of the daily pan rate, varying monthly. A sensitivity run on the final configuration used a pan factor of $75 \%$, and showed a very minor effect on the long term water levels.

\section{WASTE ROCK INFILL OPTIMISATION}

A range of practical waste rock infill configurations were derived, using the life of mine development schedule and pit shell designs, and the schedule of when mined-out pits would be available for waste rock infill. These configurations were derived in consultation with the hydrogeological and groundwater modelling team to minimise the open void area below the water table so as to minimise evaporation from any future pit void lake. Constraints were also applied to the maximum trucking distance from an active pit to a void available for infill, including minimising the haul distance for re-handling waste rock from existing and new, interim out of pit dumps. Priority was given to direct infilling of waste to mined-out areas within the same pit or to an adjacent pit. A large number of iteration loops were required to identify the waste infill distribution that achieved the guiding principle requirements and that could meet practical and cost effective mining objectives (Figures 2 and 3). 


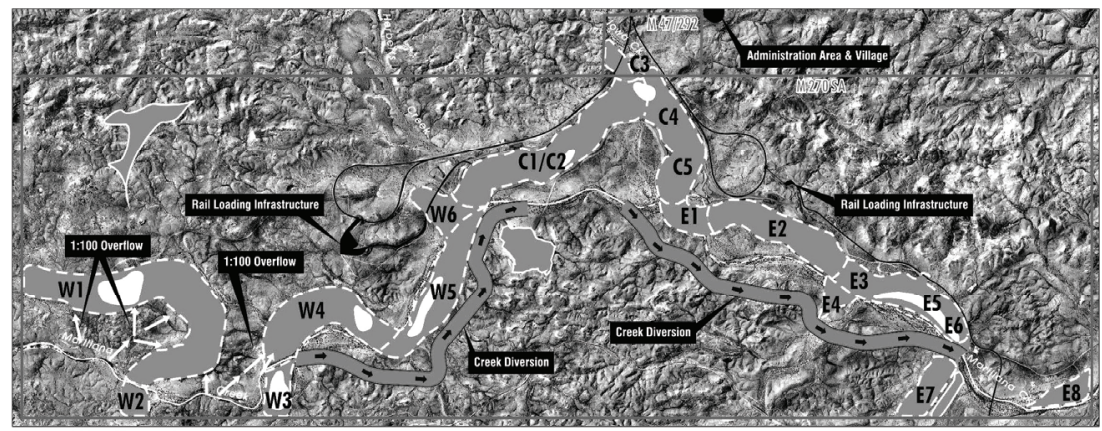

1 Conceptual Mine Closure Plan

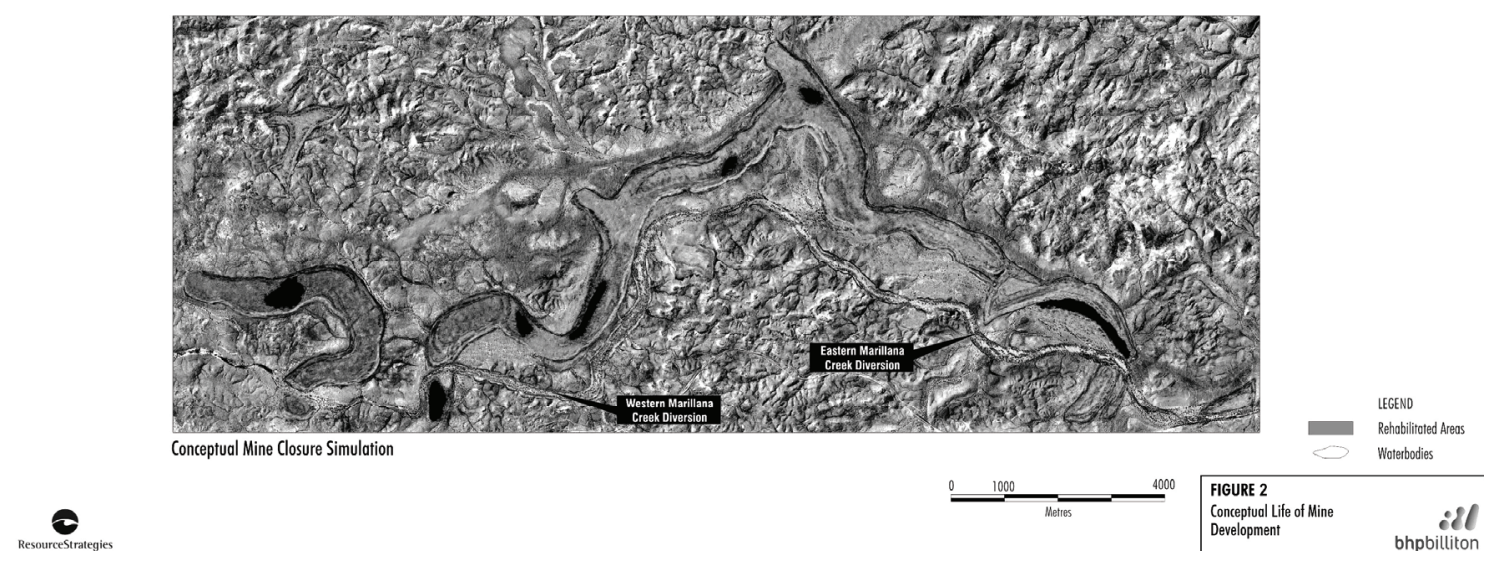

Figure 2 Conceptual life of mine development
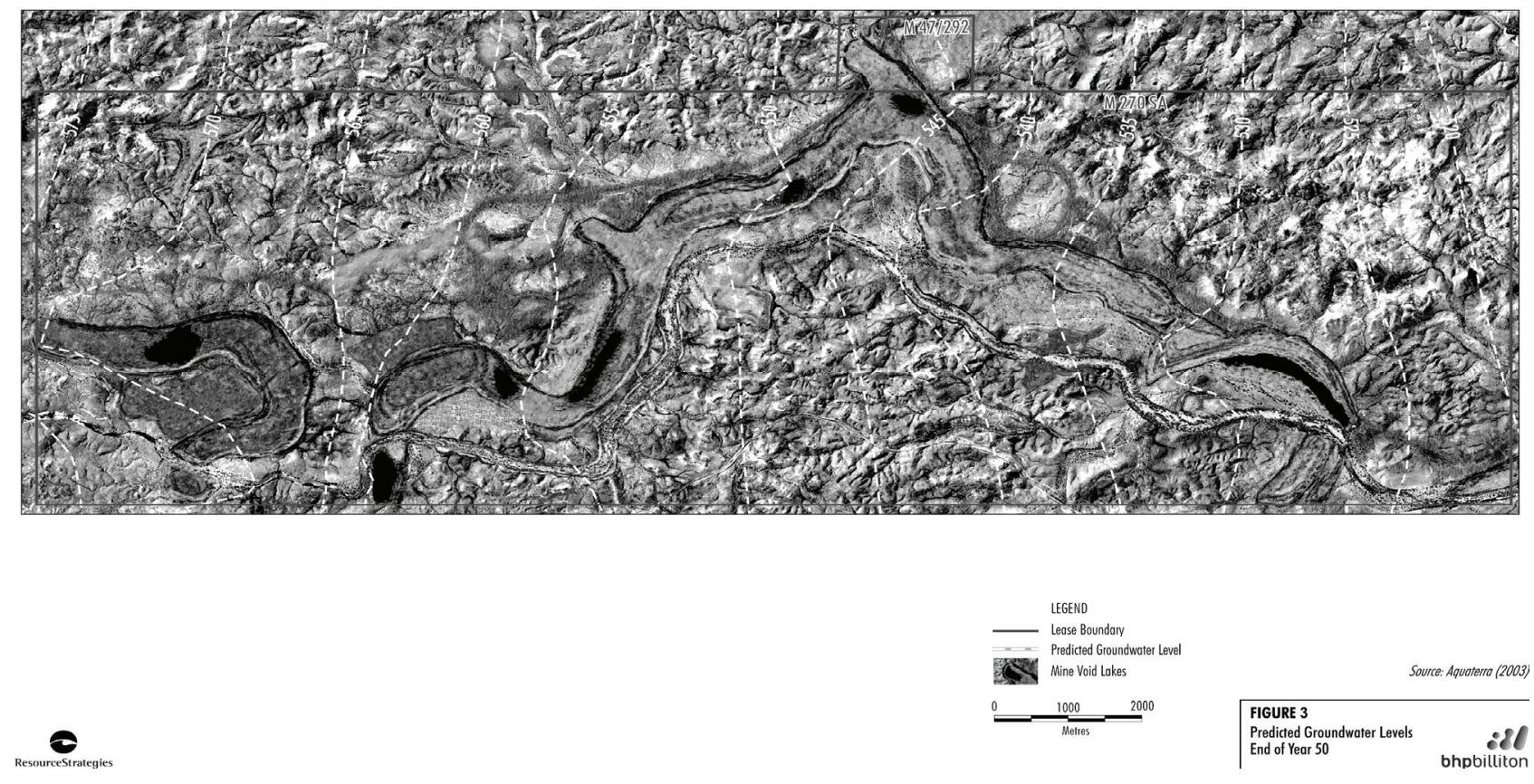

Figure 3 Predicted groundwater levels - end of year 50 
During the modelling program, it was found that the optimum infill arrangement varied, depending upon the size and shape of the final voids. For example, the waste rock infill to very long pits is usually best arranged so as to leave a narrow void (lake) along one side, and to fill the rest of the pit to above where the recovered water table will rise. The obvious approach of filling the entire pit (like a bathtub) is not practical (or achievable), because the lack of sufficient waste rock would result in the water table rising above the fill, and forming a shallow lake with a very large surface area for evaporation. For some very large pits, instead of a channel along one side, it was found that a V-shaped upper surface of waste rock infill, with the vertex at the centre of the long pit, would allow the pit lake to rise and fall in response to wet and dry periods, with the lake area expanding and contracting accordingly. This arrangement allowed a dynamic balance to develop between groundwater inflow to the void, recharge for surface water flows, evaporation from the lake and groundwater outflow.

Some of the smaller pits were able to be fully infilled, such that there would be no long term pit lake. For other medium sized pits, it was found that small, roughly circular and deep voids would result in groundwater through-flow lakes and little salinity increase. Some of these were also developed into "plunge pools" to accept surface water inflows from tributaries from the north side of the mine path (the creek diversion is the south of the mine path). The inflows provided a means of surcharging the lake levels and thus providing a recharge pulse to improve the system throughflow.

\section{ANALYTICAL MODEL FOR SALINITY PREDICTIONS}

An analytical model was developed to evaluate post closure salinity changes, rather than invoking the numerical solute transport capabilities of Modflow, which would have been very problematic in terms of simulations times and input/calibration data requirements, due to the regional scale of the groundwater flow model. The analytical model is essentially a chain of thirteen linked cells of water and salt balance mixing models for surface water and groundwater, with each cell representing one (potential) mine void, and the downstream boundary of one cell joining the upstream boundary of the next cell. The groundwater flow components for the mixing cells (inflows, outflows, stream leakage, evaporation, rainfall recharge and stream diversions) were extracted from the groundwater model results for input to the analytical model. An example of the predicted output is presented in Figure 3.

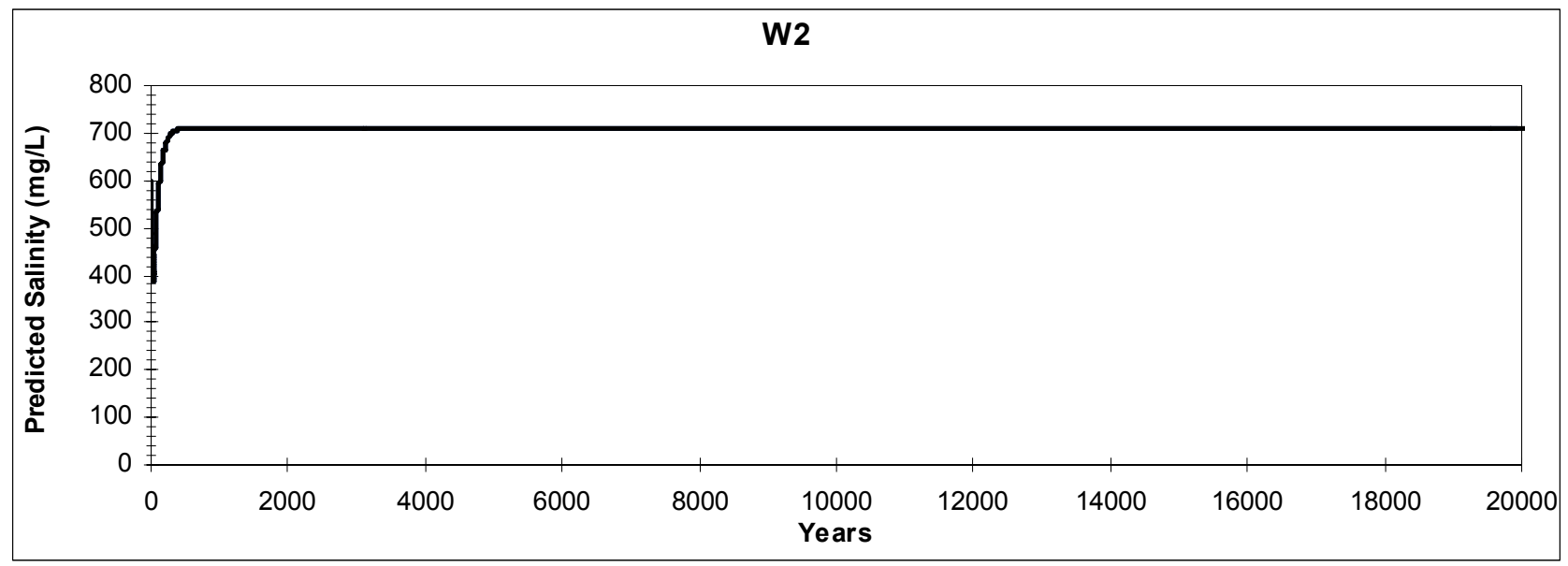

\section{Figure 4 W2 salinity prediction}

\section{$7 \quad$ PREDICTED OUTCOMES}

The results of the numerical groundwater flow modelling and the analytical salinity modelling, and the results of numerical surface water modelling (not covered in this paper) show the following predicted outcomes as a result of the adopted waste infill plan:

- Groundwater outflows: There will continue to be groundwater outflow from the BHPBIO lease, but long term flows will be less than half of the pre-mining flows. The annual volume of flow 
contribution from groundwater is very small in relation to the water budget for the terminal Fortescue March system.

- Groundwater and Pit Lake Salinity: Salinity within the final pit lakes is predicted to rise to maximum equilibrium salinity levels generally in the range of 700 to $2000 \mathrm{mg} / \mathrm{L}$ TDS within a few hundred years. Some pits are predicted to rise to levels of 2000 TDS, and one pit in the middle of the mine path was predicted to increase to 8000 TDS over a period of 4000 years. All these values remain within the beneficial use status of stock water quality. At the downstream end of the mine path, the groundwater outflow is predicted to have an equilibrium salinity of 1100 TDS after 2000 years.

- Surface Water Flows: Long term surface water flows in Marillana Creek, which carries the major part of downstream flow volumes contributions for the combined surface and groundwater system, are predicted to decrease by around 10\% compared to pre-mining conditions.

\section{CONCLUSION}

The solution developed is a cost-effective long term mine plan for BHPBIO's Yandi mine that meets all mine closure objectives, and involved:

- The development of a life of mine waste management plan that involves selective infilling of all pits, largely using run-of-mine waste dumping with limited re-handling.

- The diversion of the major part of up-catchment creek flows around the mining operations to restrict overall aquifer recharge and reduce the elevation of the long term water table.

- The diversion of some minor creek tributary flows into specific locations within the mine path to induce hydraulic gradients to maintain groundwater throughflow and water quality.

- Close integration of mine plan optimisation (mining and waste dumping schedules) with groundwater modelling scenarios to achieve acceptable environmental outcomes within the context of practical mine and waste scheduling.

This approach is predicted to result in no reduction in downstream surface water flows or quality, maintenance of adequate downstream groundwater throughflow to support groundwater dependent ecosystems, and no reduction in the beneficial use status of the downstream groundwater resource. This approach and predicted outcome form key platforms of BHPBIO's overall life of mine decommissioning and final rehabilitation plan. This plan has been accepted by the regulators as part of approvals process for the expansion of mining at Yandi.

\section{REFERENCES}

Aquaterra (2000) Central Pilbara Study. Marillana Creek Groundwater Model. Report to Water and Rivers Commission. November 2000.

BHP Billiton Iron Ore (2004) Marillana Creek (Yandi) Mine. Decommissioning and Final Rehabilitation Plan. January 2004.

Gilbert and Associates (2003) Yandi Iron Ore Mine. Hydrological and Hydraulic Assessment of Proposed Diversion of Marillana Creek for Life of Mine and Closure Concept Plan. Report to BHPBIO.

Kalf and Associates (2000) Yandi Model Review. Unpublished report to BHP Iron Ore Ltd.

Middlemis, H. and Rozlapa, K.L. (1998) Stream-Aquifer Interaction Model for Mining Below the Water Table in the Pilbara, Western Australia. Proceedings International Groundwater Conference: Groundwater: Sustainable Solutions. International Association of Hydrogeologists, Australian Chapter. 